\title{
Body fat assessed from total body density and its estimation from skinfold thickness: measurements on 481 men and women aged from 16 to 72 years
}

\author{
By J. V. G. A. DURNIN AND J. WOMERSLEY \\ Institute of Physiology, The University, Glasgow G12 8QQ \\ (Received 16 May 1973-Accepted 12 Fune 1973)
}

\begin{abstract}
I. Skinfold thicknesses at four sites - biceps, triceps, subscapular and supra-iliac - and total body density (by underwater weighing) were measured on 209 males and 272 females aged from 16 to 72 years. The fat content varied from 5 to $50 \%$ of body-weight in the men and from 10 to $61 \%$ in the women.

2. When the results were plotted it was found necessary to use the logarithm of skinfold measurements in order to achieve a linear relationship with body density.

3. Linear regression equations were calculated for the estimation of body density, and hence body fat, using single skinfolds and all possible sums of two or more skinfolds. Separate equations for the different age-groupings are given. A table is derived where percentage body fat can be read off corresponding to differing values for the total of the four standard skinfolds. This table is subdivided for sex and for age.

4. The possible reasons for the altered position of the regression lines with sex and age, and the validation of the use of body density measurements, are discussed.
\end{abstract}

The fat content of the human body has physiological and medical importance. It may influence morbidity and mortality, it may alter the effectiveness of drugs and anaesthetics, and it may affect the ability to withstand exposure to cold and starvation. Thus the measurement of the total body fat provides useful information.

In many people, but by no means everyone, a moderately satisfactory estimate of the body fat content can be obtained from the height and weight. However, for more precise evaluation several methods are available which give a reasonably accurate measure of body fat both in normal subjects and in individuals with unusual body builds. Most of these methods are based on the assumption that the body can be considered to consist of two compartments of relatively constant composition but which are distinctly different; these compartments are: (I) the body fat, which includes the entire content of chemical fat or lipids in the body, and (2) the fat-free mass (FFM), which includes all the rest of the body apart from fat.

The body fat compartment is anhydrous, contains no potassium and has a fairly constant density of about $0.90 \times 10^{3} \mathrm{~kg} / \mathrm{m}^{3}$. The fat-free compartment on the other hand probably has a fairly constant density of about $\mathrm{I} \cdot \mathrm{IO} \times 10^{3} \mathrm{~kg} / \mathrm{m}^{3}$, a potassium content of about 68 mequiv. $/ \mathrm{kg}$ in males (about 10\% less in females) and a water content of about $720 \mathrm{~g} / \mathrm{kg}$. Thus measurement of body density or of total body $\mathrm{K}$ or of total body water allows a calculation of the relative proportion of these two compartments in the body and therefore also of the total fat content. The accuracy of these measures, however, is limited by the variability of the composition and density of the fat-free compartment in different individuals. In particular, individuals with a relatively high or 
Table $\mathrm{r}$. Mean heights and weights of the subjects, with the standard deviation and range of values, classified in age-groups

\begin{tabular}{|c|c|c|c|c|c|c|c|}
\hline \multirow{2}{*}{$\begin{array}{c}\text { Age } \\
\text { (years) }\end{array}$} & \multirow{2}{*}{$\begin{array}{l}\text { No. of } \\
\text { subjects }\end{array}$} & \multicolumn{3}{|c|}{ Height (m) } & \multicolumn{3}{|c|}{ Weight (kg) } \\
\hline & & Mean & SD & Range & Mean & SD & Range \\
\hline \multicolumn{8}{|c|}{ Males } \\
\hline $17-19$ & 24 & $I \cdot 78$ & 0.088 & $x \cdot 65-I \cdot 92$ & $73 \cdot 1$ & $I 6 \cdot I$ & $50 \cdot 8-121 \cdot 4$ \\
\hline $20-29$ & 92 & $x \cdot 77$ & 0.069 & $I \cdot 52-I \cdot 93$ & $70 \cdot 1$ & $12 \cdot 2$ & $49 \cdot 8-116 \cdot 5$ \\
\hline $30-39$ & 34 & $I \cdot 76$ & 0.056 & $I \cdot 63-I \cdot 89$ & 79.8 & 10.4 & $6 r \cdot 7-118 \cdot 6$ \\
\hline $40-49$ & 35 & $I \cdot 75$ & 0.070 & I.63-I.87 & $76 \cdot 9$ & $9 \cdot 2$ & $62 \cdot 0-95 \cdot 7$ \\
\hline $50-72$ & 24 & $1 \cdot 72$ & 0.078 & $I \cdot 50-1.87$ & 80.4 & II $\cdot 7$ & $60 \cdot 3-101 \cdot 4$ \\
\hline \multicolumn{8}{|c|}{ Females } \\
\hline $16-19$ & 29 & $r \cdot 63$ & 0.056 & $I \cdot 50-I \cdot 72$ & $57 \cdot 8$ & 10.9 & $42 \cdot 3-85 \cdot 2$ \\
\hline $20-29$ & 100 & $x \cdot 63$ & 0.061 & $x \cdot 46-x \cdot 78$ & $63 \cdot 2$ & 14.4 & $46.7-113.7$ \\
\hline $30-39$ & 58 & $x \cdot 62$ & 0.052 & $I \cdot 52-I \cdot 73$ & $68 \cdot I$ & $16 \cdot x$ & $43.9-108 \cdot 9$ \\
\hline $40-49$ & 48 & $1 \cdot 62$ & 0.066 & $1 \cdot 46-1 \cdot 77$ & $68 \cdot 1$ & I 3.8 & $50 \cdot 3-116 \cdot 3$ \\
\hline $50-68$ & 37 & $I-6 r$ & 0.060 & $r \cdot 49-r \cdot 72$ & $69 \cdot 1$ & $16 \cdot 1$ & $44 \cdot 4-121 \cdot 5$ \\
\hline
\end{tabular}

low proportion of bone (which has a low water and $\mathrm{K}$ content but a high density compared with the rest of the FFM) may have their fat content under- or over-estimated by these methods. Very little information is available on the variability of the bone content of the body. Similar considerations apply, although to a lesser degree, to individuals who have an abnormally high or low proportion of muscle.

Measurements of total body water, total body $\mathrm{K}$, or of body density are difficult procedures requiring complex laboratory equipment, and frequent attempts have been made to find a simple technique which will give good agreement with these more established methods. One possibility involves the measurement of skinfold thickness. A previous paper from this laboratory (Durnin \& Rahaman, I967) suggested that the relationship between body density and skinfolds was sufficiently uniform that regression equations and tables could be constructed to calculate body fat on this basis in adolescents and young adults. The purpose of this paper is to examine the relationship between skinfold thickness and body density in individuals of widely different age-groups, and also to determine the accuracy with which body density can be estimated from measurements of skinfolds.

\section{EXPERIMENTAL}

\section{Subjects}

Studies were made on 209 men and 272 women between the ages of 16 and 72 . The numbers of subjects in each of the age-groups $16-19,20-29,30-39,40-49$ years, and 50 years and over are given in Table I together with the means, standard deviations and ranges of their heights and weights. No attempt was made to obtain a random sample of the population and there is probably a preponderance of moderately sedentary, middle-class men and women (students, business and professional men and women and their spouses). However, the subjects were deliberately selected to represent a variety of body types (some volunteers were obtained from an obesity clinic, 
from local health clubs and sports organizations, a ballet company and other sources). All the subjects were apparently healthy.

\section{Skinfold thickness and body circumferences}

Skinfold thickness was measured to the nearest $\mathrm{mm}$, except for low values (usually $5 \mathrm{~mm}$ or less) when it was taken to the nearest $0.5 \mathrm{~mm}$. These readings were made at four sites on all subjects, at the biceps, triceps, subscapular and supra-iliac areas. These were usually done on the right side of the body with the subject standing in a relaxed condition, although we have not found any statistical difference between measurements on either side of the body (Womersley \& Durnin, r973). Nor, apparently, is there any effect caused on the overlying subcutaneous fat of muscular activity in the limb, so that the skinfold thickness of a tennis player is no different at the upper arm sites in the active arm compared to the less active arm (Gwinup, Chelvam \& Steinberg, 1971). The instrument used was either the Harpenden caliper (Holtain Ltd, Bryberian, Crymmych, Pembrokeshire) or the Lange caliper (Cambridge Scientific Industries Inc., Cambridge, Maryland, USA); again, we have found no significant difference in the results obtained using these two calipers (Womersley \& Durnin, I973). The circumference at the upper arm, upper thigh and calf were obtained using a flexible steel tape; on some subjects the maximum circumference over the buttocks was also measured. Skinfolds and circumferences were metered by the standard technique described by Weiner \& Lourie (1969), except that the subscapular skinfold was always taken at an angle of about $45^{\circ}$ to the vertical and the position of the suprailiac skinfold was just above the iliac crest in the mid-axillary line. Body-weight was measured to the nearest $0.1 \mathrm{~kg}$ using a calibrated Avery beam balance.

\section{Body density}

The body density of each individual was found using the technique of Durnin \& Rahaman ( 1967 ) and the volume of air in the lungs at the moment of underwater weighing was measured by the three-breath nitrogen dilution method (Rahn, Fenn \& Otis, 1949). The $\mathrm{O}_{2}$ content in the bag was obtained using a Servomex paramagnetic $\mathrm{O}_{2}$ analyser (Model OA ror, Mark II), calibrated using standard gas mixtures maintained in cylinders which, in their turn, were calibrated using a Lloyd-Haldane apparatus. A Hartmann \& Braun infrared analyser was used for $\mathrm{CO}_{2}$ analysis, similarly calibrated.

The whole procedure was carried out in triplicate with an interval of at least $5 \mathrm{~min}$ between measurements. Calculations of density were completed using an Olivetti desk computer while the subject remained in the tank so that, in the unusual event of there being poor agreement between the three sets of results, a further measurement could be done. Body fat was calculated from density using Siri's (1956) equation,

$$
\% \text { fat }=\left(\frac{4.95}{\text { density }}-4.50\right) \times 100
$$

although no significant difference arises from the use of the equation of Brozek, Grande, Anderson \& Keys (1963). 
Table 2. Mean skinfold thicknesses $(\mathrm{mm})$ of the subjects at four sites, with the standard deviation and range of values, classified in age-groups

\begin{tabular}{|c|c|c|c|c|c|c|c|c|c|c|c|c|c|}
\hline \multirow{2}{*}{$\begin{array}{c}\text { Age } \\
\text { (years) }\end{array}$} & \multirow{2}{*}{$\begin{array}{l}\text { No. of } \\
\text { subjects }\end{array}$} & \multicolumn{3}{|c|}{ Biceps } & \multicolumn{3}{|c|}{ Triceps } & \multicolumn{3}{|c|}{ Subscapular } & \multicolumn{3}{|c|}{ Supra-iliac } \\
\hline & & Mean & SD & Range & Mean & SD & Range & Mean & SD & Range & Mean & SD & Range \\
\hline \multicolumn{14}{|c|}{ Males } \\
\hline $17-19$ & 24 & $4 \cdot 6$ & $3 \cdot 0$ & $2-13$ & II & $7 \cdot 0$ & $4-35$ & II & $6 \cdot 5$ & $5^{-24}$ & 14 & $\mathrm{I} 2$ & $4-52$ \\
\hline $20-29$ & 92 & 4.8 & $4 \cdot 2$ & $2-29$ & $9 \cdot 8$ & $5 \cdot 8$ & $3-39$ & 12 & 8.9 & $5-58$ & 16 & 12 & $3-59$ \\
\hline $30-39$ & 34 & $7 \cdot 1$ & $4 \cdot I$ & $4-23$ & II & $5 \cdot 2$ & $9-33$ & 19 & 9.5 & $10-47$ & 24 & 8.9 & $12-44$ \\
\hline $40-49$ & 35 & $7 \cdot 1$ & $4 \cdot 3$ & $3-20$ & II & $5 \cdot 6$ & $5^{-29}$ & 17 & $7 \cdot 3$ & $7-38$ & 19 & 8.6 & $5-40$ \\
\hline $50-72$ & 24 & $6 \cdot 6$ & $3 \cdot 8$ & $2-16$ & II & $5 \cdot 9$ & $4^{-27}$ & $2 \mathrm{I}$ & IO & $9-52$ & $2 I$ & II & $6-52$ \\
\hline \multicolumn{14}{|c|}{ Females } \\
\hline $16-19$ & 29 & 8.7 & $5 \cdot 4$ & $4-27$ & 16 & 8.0 & $5-4 I$ & 14 & $9 \cdot 4$ & $6-45$ & 16 & $9 \cdot 3$ & $4-36$ \\
\hline $20-29$ & 100 & II & 7.5 & $2-36$ & 21 & Io & $7-50$ & 18 & II & $5-48$ & 18 & 12 & $4-48$ \\
\hline $30-39$ & 58 & 15 & IO & $4-45$ & 25 & 12 & $7-54$ & 24 & I 5 & $7-57$ & 21 & 13 & $6-56$ \\
\hline $40-49$ & $4^{8}$ & 14 & 8.I & $4-44$ & 23 & ro & $10-55$ & 22 & II & $8-56$ & 19 & 12 & $6-60$ \\
\hline $50-68$ & 37 & I5 & $7 \cdot 9$ & $5-36$ & 25 & $9 \cdot 7$ & $13-49$ & 24 & II $\cdot 7$ & $7 \cdot 57$ & 23 & 14 & $5-60$ \\
\hline
\end{tabular}

Linear regression equations were formulated to estimate body density from single skinfold measurements, and from the sums of two or more skinfolds. These calculations were carried out for the five age-groups of both sexes, and also for groups comprising all the members of each sex over the age of 17 years for males and 16 years for females.

Similar calculations were carried out using the logarithm of each skinfold thickness rather than the actual measurement (Edwards, Hammond, Healy, Tanner \& Whitehouse, 1955; Tanner, 1962; Tanner \& Whitehouse, 1962). The logarithmic transformation is desirable because $(a)$ the frequency distribution of most skinfold measurements in the general population is skewed, with a long tail of high readings (although this may well represent a pathological state of common obesity) and $(b)$ the relationship of body density to skinfolds may not be rectilinear because of a larger proportion of the body fat which is deposited subcutaneously with increasing obesity. Also, since it has been suggested (Edwards et al. ${ }^{1955)}$ that subtraction of $\mathrm{r} .8 \mathrm{~mm}$ (which is supposed to be the thickness of a double layer of skin when the caliper tension is $9.8 \times 10^{4} \mathrm{~N} / \mathrm{m}^{2}$ from each measurement of skinfold might provide a better correlation with density, these calculations were repeated on this basis, both in logarithmic and non-logarithmic form.

Multiple regression analyses were then carried out for the calculation of body density, incorporating measurements of limb circumferences, height and weight to try and reduce the error of the estimate.

\section{RESULTS}

The values obtained for the skinfold thicknesses at the four separate sites are given in Table 2.

Table 3 shows the values for the total of the four skinfolds, the density, and the fat content of the body expressed as a percentage of body-weight. 
Table 3. Total of four skinfolds, total body density and fat content of the subjects, classified in age-groups

\begin{tabular}{|c|c|c|c|c|c|c|c|c|c|c|}
\hline \multirow{2}{*}{$\begin{array}{c}\text { Age } \\
\text { (years) }\end{array}$} & \multirow{2}{*}{$\begin{array}{l}\text { No. of } \\
\text { subjects }\end{array}$} & \multicolumn{3}{|c|}{ Total skinfold (mm) } & \multicolumn{3}{|c|}{ Density $\times 10^{8}\left(\mathrm{~kg} / \mathrm{m}^{3}\right)$} & \multicolumn{3}{|c|}{ Fat ( $\%$ of body-wt) } \\
\hline & & Mean & SD & Range & Mean & SD & Range & Mean & SD & Range \\
\hline \multicolumn{11}{|c|}{ Males } \\
\hline$x_{7}-x_{9}$ & 24 & 40 & 27 & $16-114$ & $x \cdot 066$ & 0.016 & $1 \cdot 033-1 \cdot 082$ & $I_{5}$ & $7 \cdot 0$ & $7-30$ \\
\hline $20-29$ & 92 & 42 & 29 & $16-182$ & $1 \cdot 06_{4}$ & 0.016 & I.016-1.087 & I 5 & $7 \cdot 0$ & $5-38$ \\
\hline $30-39$ & 34 & 62 & 25 & $30-145$ & $x \cdot 046$ & 0.012 & $x \cdot 015-r \cdot 070$ & 23 & $5 \cdot 4$ & $13-38$ \\
\hline $40-49$ & 35 & 55 & 24 & $22-123$ & $I \cdot 043$ & 0.015 & $I \cdot 017-1 \cdot 073$ & 25 & $6 \cdot 7$ & $1 I-37$ \\
\hline $50-72$ & 24 & 61 & 30 & $21-142$ & 1.036 & 0.018 & $0.990-I .074$ & 28 & $8 \cdot 5$ & $I I-50$ \\
\hline \multicolumn{11}{|c|}{ Females } \\
\hline 16-19 & 29 & 55 & 30 & $22-123$ & 1.040 & 0.017 & $I \cdot 004-I \cdot 067$ & 26 & $7 \cdot 8$ & $14-43$ \\
\hline $20-29$ & roo & 66 & 39 & $23-140$ & $1 \cdot 034$ & 0.021 & $0.983-1 \cdot 078$ & 29 & 10 & $10-54$ \\
\hline $30-39$ & 58 & 85 & 48 & $20-172$ & 1.025 & 0.020 & $0.985-1.077$ & 33 & $9 \cdot 5$ & $19-53$ \\
\hline $40-49$ & 48 & 78 & 38 & $26-196$ & 1.020 & 0.016 & $0.968-1.045$ & 35 & $7 \cdot 5$ & $24-6 I$ \\
\hline $50-68$ & 37 & 86 & $4 I$ & $34-202$ & $\mathrm{I} \cdot \mathrm{Or}_{3}$ & 0.016 & $0.986-I \cdot 04 I$ & 39 & $7 \cdot 6$ & $26-52$ \\
\hline
\end{tabular}

The correlation coefficients for sums of two and more skinfolds (in the logarithmic transformation) and body density varied from about -0.7 to -0.9 for the different age-groups of both the men and the women.

Table 4 shows the standard errors of the estimate of density using the logarithm of each of the four separate skinfolds, the logarithm of combinations of two and more skinfolds, and the logarithm of the sum of the four skinfolds in the respective linear regression equations. The SEs for the logarithmic form are slightly lower than those for the raw measurement in the men whereas there is no consistent difference in the women. The SE of the estimate is considerably greater in both sexes for the combined age-group 17 years and over than for the selected smaller age-ranges.

When a deduction of $\mathrm{I} \cdot 8 \mathrm{~mm}$ was made from each measurement of skinfold thickness, no significant alteration was obtained in the SE of the estimate of density (the SE actually increased for the log values) nor in the correlation coefficients of density and skinfolds. Therefore, there seems no practical advantage in making this adjustment.

The pooled SE of the estimate of body density obtained from the linear regression equation using the logarithmic transformation of the sum of the four skinfold thicknesses was 0.0084 (range $0.0073^{-0.0092)}$ for the groups of men and 0.0102 (range $0.0082-0.0125$ ) for the women. When multiple regression analyses were done using the four individual skinfolds, there was no reduction in the SE for the men and a diminution of 0.007 units (equivalent to $0.3 \%$ fat) for the women. Multiple regression analyses incorporating height and weight again caused no improvement in the SE in the case of the men and a reduction of 0.005 units $(0.25 \%$ fat) for the women. No consistent change resulted from including limb circumferences. From our results, the use of the more complex equations results in minimal increase in accuracy. 
Table 4. Standard errors of the estimate of body density obtained from regression on log of skinfold measurements

(a) Males

Skinfold
Biceps
Triceps
Subscapular
Supra-iliac
Biceps + triceps
Biceps + subscapular
Biceps + supra-iliac
Triceps + subscapular
Triceps + supra-iliac
Subscapular +supra-iliac
Biceps + triceps + subscapular
Biceps + triceps + supra-iliac
Biceps + subscapular +
supra-iliac
Triceps + subscapular +
supra-iliac
All four skinfolds

\begin{tabular}{llllll}
\multicolumn{7}{c}{ Age (years) } \\
\hline $17-19$ & $20-29$ & $30-39$ & $40-49$ & $50-68$ & $17-72$ \\
0.0066 & 0.0096 & 0.0092 & 0.0095 & 0.0120 & 0.0115 \\
0.0077 & 0.0113 & 0.0105 & 0.0090 & 0.0117 & 0.0141 \\
0.0083 & 0.0081 & 0.0091 & 0.0085 & 0.0102 & 0.0097 \\
0.0103 & 0.0101 & 0.0098 & 0.0111 & 0.0105 & 0.0126 \\
0.0062 & 0.0102 & 0.0096 & 0.0086 & 0.0112 & 0.0124 \\
0.0071 & 0.0080 & 0.0088 & 0.0080 & 0.0100 & 0.0094 \\
0.0091 & 0.0094 & 0.0092 & 0.0102 & 0.0102 & 0.0116 \\
0.0065 & 0.0089 & 0.0090 & 0.0070 & 0.0096 & 0.0102 \\
0.0083 & 0.0094 & 0.0094 & 0.0090 & 0.0098 & 0.0118 \\
0.0089 & 0.0086 & 0.0090 & 0.0095 & 0.0091 & 0.0105 \\
0.0059 & 0.0087 & 0.0089 & 0.0073 & 0.0097 & 0.0100 \\
0.0077 & 0.0091 & 0.0091 & 0.0088 & 0.0099 & 0.0114 \\
0.0083 & 0.0084 & 0.0088 & 0.0091 & 0.0092 & 0.0102 \\
0.0077 & 0.0085 & 0.0088 & 0.0082 & 0.0090 & 0.0104 \\
0.0073 & 0.0084 & 0.0087 & 0.0082 & 0.0092 & 0.0103
\end{tabular}

(b) Females

Skinfold
Biceps
Triceps
Subscapular
Supra-iliac
Biceps + triceps
Biceps + subscapular
Biceps + supra-iliac
Triceps + subscapular
Triceps + supra-iliac
Subscapular + supra-iliac
Biceps + triceps + subscapular
Biceps + triceps + supra-iliac
Biceps + subscapular +
supra-iliac
Triceps + subscapular +
supra-iliac
All four skinfolds

\begin{tabular}{cccccc}
\multicolumn{5}{c}{ Ag) Females } & (years) \\
\hline 16-19 & $20-29$ & $30-39$ & $40-49$ & $50-68$ & $17-68$ \\
0.0112 & 0.0116 & 0.0129 & 0.0115 & 0.0088 & 0.0123 \\
0.0108 & 0.0120 & 0.0134 & 0.0106 & 0.0098 & 0.0126 \\
0.0098 & 0.0108 & 0.0129 & 0.0120 & 0.0089 & 0.0119 \\
0.0111 & 0.0137 & 0.0144 & 0.0122 & 0.0098 & 0.0143 \\
0.0103 & 0.0113 & 0.0126 & 0.0102 & 0.0087 & 0.0118 \\
0.0096 & 0.0104 & 0.0122 & 0.0113 & 0.0082 & 0.0114 \\
0.0104 & 0.0125 & 0.0134 & 0.0114 & 0.0088 & 0.0130 \\
0.0086 & 0.0102 & 0.0123 & 0.0109 & 0.0084 & 0.0113 \\
0.0099 & 0.0121 & 0.0132 & 0.0105 & 0.0090 & 0.0125 \\
0.0091 & 0.0118 & 0.0132 & 0.0116 & 0.0090 & 0.0125 \\
0.0090 & 0.0102 & 0.0121 & 0.0107 & 0.0080 & 0.0111 \\
0.0098 & 0.0117 & 0.0128 & 0.0104 & 0.0085 & 0.0121 \\
0.0087 & 0.0111 & 0.0127 & 0.0108 & 0.0085 & 0.0120 \\
0.0093 & 0.0114 & 0.0128 & 0.0112 & 0.0085 & 0.0118 \\
0.0089 & 0.0109 & 0.0125 & 0.0107 & 0.0082 & 0.0116
\end{tabular}

\section{DISCUSSION}

Fig. I shows plots of the values for body density and the sum of the four skinfolds for the 116 men and 129 women aged between 16 and 29 years. It is evident that the relationship between body density and skinfold is not a linear one in either sex: in the more obese subjects relatively large increments in skinfold thickness are associated with only small changes in body density. The relationship would seem from inspection of the plots to be logarithmic or quadratic in form, and since the range of densities which correspond to a single value for skinfold thickness is often considerable it is unlikely to matter which of these two relationships is chosen. For ease of calculation therefore it was decided to assume a logarithmic relationship for subsequent 

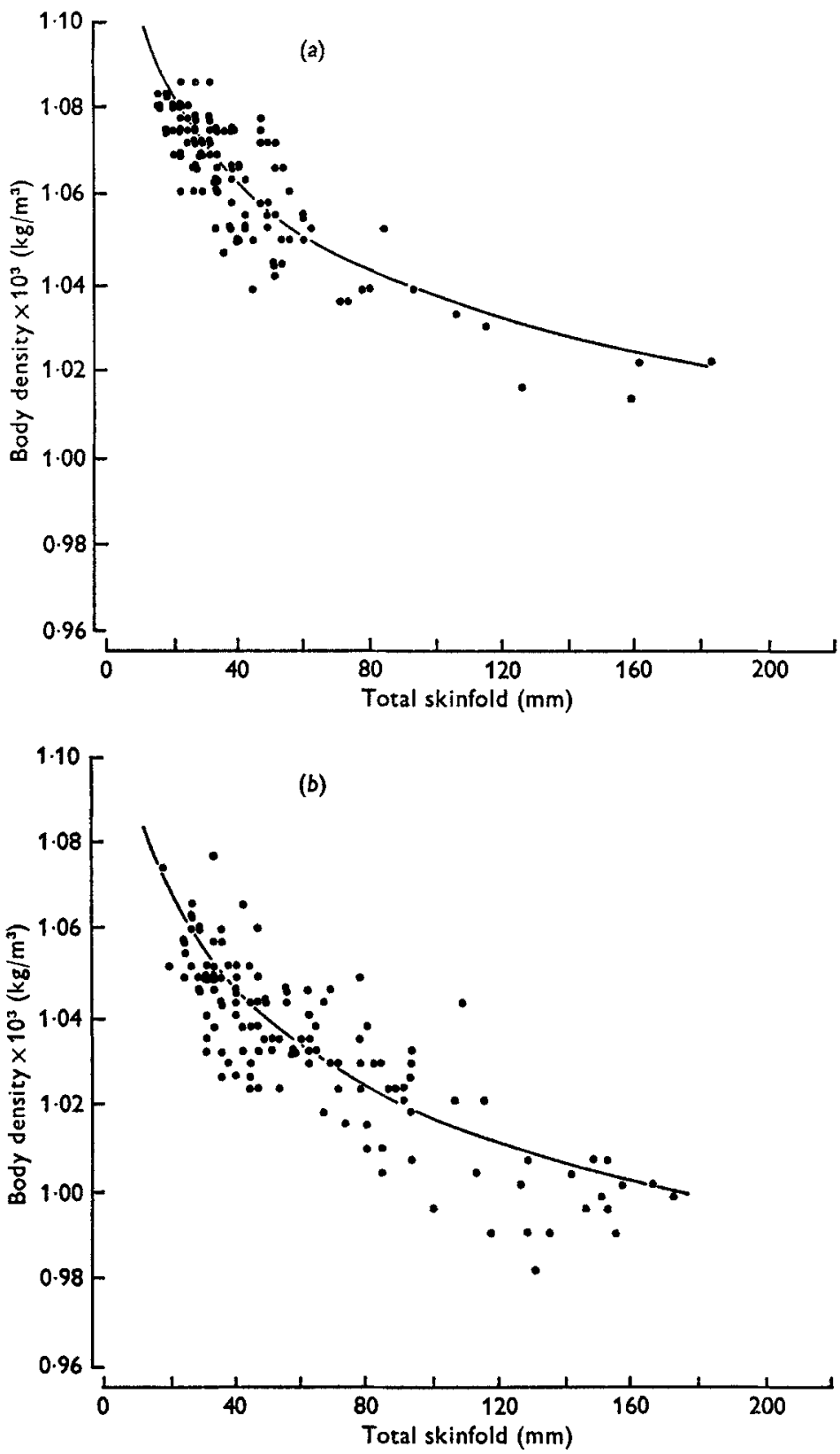

Fig. I ( $a$ ) Individual values for body density and sum of four skinfolds with best-fit regression line derived from log values of skinfolds: I 16 men aged 17-29. (b) Individual values for body density and sum of four skinfolds with best-fit regression line derived from log values of skinfolds : 129 women aged $16-29$. 

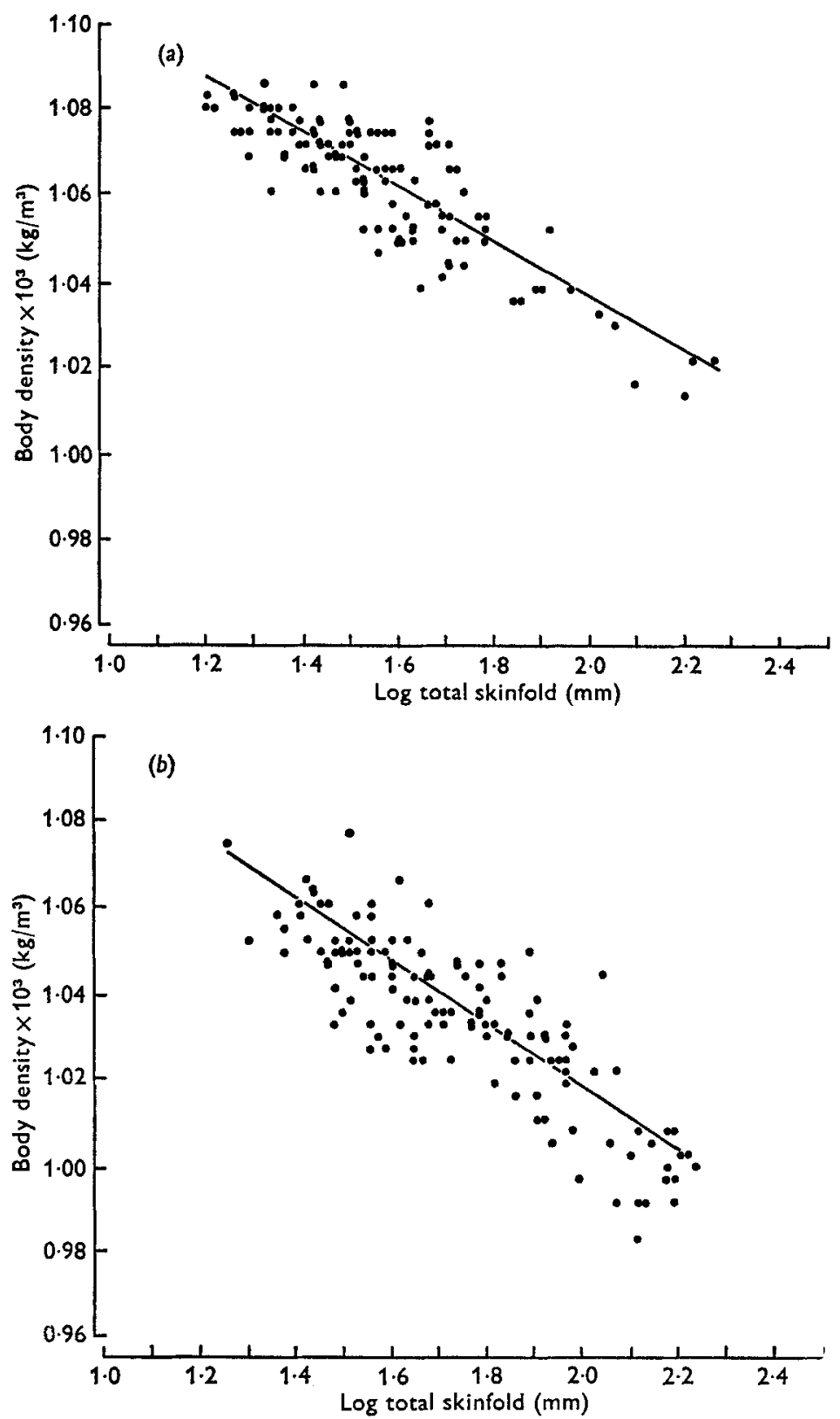

Fig. 2 (a) Individual values for body density and log of sum of four skinfolds: 1 I 6 men aged 1 7-29 years. (b) Individual values for body density and $\log$ of sum of four skinfolds: I 29 women aged $16-29$ years.

work, and the best-fit logarithmic regression line is shown in the figure. The plots for the other age-groups are similar.

Fig. 2 shows the values for body density and the logarithm of the sum of the four skinfolds for the I6- to 29-year-old men and women. The relationship is now apparently linear in form and the regression line of best fit is shown in each instance. 
Table 5 gives, for the different age-groupings in men and in women, all the linear regression equations for the estimation of density from the logarithm of skinfold thickness using single skinfolds and the sums of two or more skinfold thicknesses.

Fig. 3 shows the relationships between the regression lines of the logarithm of the total skinfold thickness (the sum of the four single skinfolds) and body density for the different age-groups of the men and women.

Figs. 4 and 5 demonstrate that most of the single skinfolds show the same pattern as that of the four total skinfolds. The gradient for the regression lines is less for the supra-iliac than for the other skinfolds, possibly reinforcing the common impression that relatively more fat is deposited in that region compared to other sites in the body (also cf. Table 5).

The regression coefficients for the five age-groups of men and of women were tested for significant difference (Table 6) and this was found to exist only in one out of these ten groups; the subscapular skinfold in men. The other skinfolds showed no significant variation in slope and a joint estimate of the slope was calculated in these instances, together with intercepts estimated assuming a common slope (Table 7).

Table 7 shows a consistent trend for the intercept to become lower as age increases in all skinfolds, the only qualification being that in three skinfolds (suprailiac and total skinfolds for men and triceps for women) there is a negligible change between the 16-19- and the 20-29-year-old groups. Even the single skinfold (subscapular in men) which showed significant differences in slope of the regression lines, also demonstrates the lower position of the lines as age increases (see Fig. $4 c$ ).

Table 8 shows that the regression lines of body density on skinfold thickness for which a common slope could be estimated were highly significantly different for the different age-groups, and this justifies the separate consideration of the relationship for each age-group.

It is thus apparent that both sex and age exert an influence on the position of these regression lines. In the relationships between skinfold thickness and body density, a given skinfold corresponds to a considerably lower body density in women than in men, and this implies that in women a greater proportion of the body fat content is situated internally. In the females the value for body density which corresponds to a given total of four skinfold thicknesses decreases by about $0.15 \times 10^{3} \mathrm{~kg} / \mathrm{m}^{3}$ between early adulthood and the ' $50+$ ' group - about $0.004 \times 10^{3} \mathrm{~kg} / \mathrm{m}^{3}$ per decade. This decrement is slightly greater in the men (about $0.005 \times 10^{3} \mathrm{~kg} / \mathrm{m}^{3}$ per decade) and is more marked in the more obese individuals.

\section{(a) The proportion of body fat situated subcutaneously}

One possible reason for the change in position of the regression lines with ageing (as also in the instance of the sex difference) may be that a greater proportion of the total body fat is situated internally than subcutaneously. Evidence that this might be the situation has been put forward by Skerlj, Brozek \& Hunt (I953); in a study on three groups of women, one aged from 18 to 30 years, a second from $3 \mathrm{I}$ to 45 years, and a third from 46 to 67 years, they found that the ratio, subcutaneous fat: total body fat was 0.26 in the first two groups but had fallen to 0.22 in the third and oldest group. 
Table 5. Linear regression equations for the estimation of body density $\times 1 \mathrm{I}^{3}\left(\mathrm{~kg} / \mathrm{m}^{3}\right)$ from the logarithm of the skinfold thickness: density $=c-m \times \log$ skinfold

(a) Males Age (years)

Skinfold

\begin{tabular}{|c|c|c|c|c|c|c|c|}
\hline Skinfold & & $17-19$ & $20-29$ & $30-39$ & $40-49$ & $50+$ & $17-72$ \\
\hline Biceps & $\begin{array}{l}c \\
m\end{array}$ & $\begin{array}{l}\mathrm{r} \cdot 1066 \\
0.0686\end{array}$ & $\begin{array}{l}I \cdot 1015 \\
0.0616\end{array}$ & $\begin{array}{l}1.078 x \\
0.0396\end{array}$ & $\begin{array}{l}x .0829 \\
0.0508\end{array}$ & $\begin{array}{l}\mathbf{1} 0833 \\
0.0617\end{array}$ & $\begin{array}{l}I \cdot 0997 \\
0.0659\end{array}$ \\
\hline Triceps & $\begin{array}{l}c \\
m\end{array}$ & $\begin{array}{l}I \cdot 1252 \\
0.0625\end{array}$ & $\begin{array}{l}I \cdot 113 I \\
0.0530\end{array}$ & $\begin{array}{l}1.0834 \\
0.036 \mathrm{I}\end{array}$ & $\begin{array}{l}\text { I'104I } \\
0.0609\end{array}$ & $\begin{array}{l}\mathbf{I} \cdot 1027 \\
0.0662\end{array}$ & $\begin{array}{l}I \cdot 1 \text { I } 43 \\
0.0618\end{array}$ \\
\hline Subscapular & $\begin{array}{l}c \\
m\end{array}$ & $\begin{array}{l}\mathrm{I} \cdot 13 \mathrm{I} 2 \\
0.0670\end{array}$ & $\begin{array}{l}I \cdot 1360 \\
0.0700\end{array}$ & $\begin{array}{l}\mathbf{1} \cdot 0978 \\
0.0416\end{array}$ & $\begin{array}{l}1 \cdot 1246 \\
0.0686\end{array}$ & $\begin{array}{l}I \cdot r 334 \\
0.0760\end{array}$ & $\begin{array}{l}I \cdot r 369 \\
0.074 I\end{array}$ \\
\hline Supra-iliac & $\begin{array}{l}c \\
m\end{array}$ & $\begin{array}{l}I \cdot 1092 \\
0.0420\end{array}$ & $\begin{array}{l}I \cdot I I I 7 \\
0.043 I\end{array}$ & $\begin{array}{l}x \cdot 1047 \\
0.0432\end{array}$ & $\begin{array}{l}I \cdot 1029 \\
0.0483\end{array}$ & $\begin{array}{l}x \cdot 1193 \\
0.0652\end{array}$ & $\begin{array}{l}\text { I.II I I } \\
0.0530\end{array}$ \\
\hline Biceps + triceps & $\begin{array}{l}c \\
m\end{array}$ & $\begin{array}{l}\mathrm{I} \cdot 1423 \\
0.0687\end{array}$ & $\begin{array}{l}\text { I. } 1307 \\
0.0603\end{array}$ & $\begin{array}{l}I .0995 \\
0.043 I^{2}\end{array}$ & $\begin{array}{l}\text { I. II774 } \\
0.0614\end{array}$ & $\begin{array}{l}\text { I. I } 185 \\
0.0683\end{array}$ & $\begin{array}{l}I \cdot 1356 \\
0.0700\end{array}$ \\
\hline Biceps + subscapular & $\begin{array}{l}c \\
m\end{array}$ & $\begin{array}{l}I \cdot I 457 \\
0.0707\end{array}$ & $\begin{array}{l}\mathrm{I} \cdot 1469 \\
0.0709\end{array}$ & $\begin{array}{l}I \cdot 0753 \\
0.0445\end{array}$ & $\begin{array}{l}I \cdot I 34 I \\
0.0680\end{array}$ & $\begin{array}{l}I \cdot I 427 \\
0.0762\end{array}$ & $\begin{array}{l}I \cdot 1498 \\
0.0759\end{array}$ \\
\hline Biceps + supra-íliac & $\begin{array}{l}c \\
m\end{array}$ & $\begin{array}{l}\mathrm{I} \cdot 1247 \\
0.0501\end{array}$ & $\begin{array}{l}\text { I. } 1259 \\
0.0502\end{array}$ & $\begin{array}{l}I \cdot 1174 \\
0.0486\end{array}$ & $\begin{array}{l}\text { I.II7 I } \\
0.0539\end{array}$ & $\begin{array}{l}\mathrm{x} \cdot 1307 \\
0.0678\end{array}$ & $\begin{array}{l}I \cdot r 33 I \\
0.060 I\end{array}$ \\
\hline Triceps + subscapular & $\begin{array}{l}c \\
m\end{array}$ & $\begin{array}{l}\mathrm{I} \cdot 156 \mathrm{I} \\
0.07 \mathrm{II}\end{array}$ & $\begin{array}{l}I \cdot I 525 \\
0.0687\end{array}$ & $\begin{array}{l}I \cdot I 165 \\
0.0484\end{array}$ & $\begin{array}{l}\text { I. } 1519 \\
0.0771\end{array}$ & $\begin{array}{l}I \cdot 1527 \\
0.0793\end{array}$ & $\begin{array}{l}I \cdot 1625 \\
0.0797\end{array}$ \\
\hline Triceps + supra-iliac & $\begin{array}{l}c \\
m\end{array}$ & $\begin{array}{l}\mathrm{I} \cdot \mathrm{r} 370 \\
0.0545\end{array}$ & $\begin{array}{l}I \cdot r 362 \\
0.0538\end{array}$ & $\begin{array}{l}I \cdot 1273 \\
0.0531\end{array}$ & $\begin{array}{l}I \cdot 1383 \\
0.0660\end{array}$ & $\begin{array}{l}I \cdot 1415 \\
0.0718\end{array}$ & $\begin{array}{l}1.1463 \\
0.0656\end{array}$ \\
\hline Subscapular + supra-iliac & $\begin{array}{l}c \\
m\end{array}$ & $\begin{array}{l}\mathrm{I} \cdot 1374 \\
0.0544\end{array}$ & $\begin{array}{l}I \cdot I 429 \\
0.0573\end{array}$ & $\begin{array}{l}x \cdot 1260 \\
0.0497\end{array}$ & $\begin{array}{l}I 1392 \\
0.0633\end{array}$ & $\begin{array}{l}I .1582 \\
0.0771\end{array}$ & $\begin{array}{l}1.1522 \\
0.0671\end{array}$ \\
\hline Biceps + triceps + subscapular & $c$ & $\begin{array}{l}x \cdot 1643 \\
0 \cdot 0727\end{array}$ & $\begin{array}{l}I \cdot r 593 \\
0.0694\end{array}$ & $\begin{array}{l}x \cdot 1213 \\
0.0487\end{array}$ & $\begin{array}{l}\text { I. } 530 \\
0.0730\end{array}$ & $\begin{array}{l}I \cdot 1569 \\
0.0780\end{array}$ & $\begin{array}{l}I \cdot x 689 \\
0.0793\end{array}$ \\
\hline Biceps + triceps + supra-iliac & $\begin{array}{l}c \\
m\end{array}$ & $\begin{array}{l}I \cdot I 466 \\
0.0584\end{array}$ & $\begin{array}{l}\mathrm{I} \cdot \mathrm{I} 45 \mathrm{I} \\
0.0572\end{array}$ & $\begin{array}{l}x \cdot I 332 \\
0.0542\end{array}$ & $\begin{array}{l}\text { I. } 1422 \\
0.0647\end{array}$ & $\begin{array}{l}I \cdot 1473 \\
0.0718\end{array}$ & $\begin{array}{l}\text { I.r } 556 \\
0.0683\end{array}$ \\
\hline $\begin{array}{l}\text { Biceps + subscapular }+ \\
\text { supra-iliac }\end{array}$ & $\begin{array}{l}c \\
m\end{array}$ & $\begin{array}{l}I \cdot 1469 \\
0.0583\end{array}$ & $\begin{array}{l}I \cdot 1508 \\
0.0599\end{array}$ & $\begin{array}{l}x \cdot 13 \times 5 \\
0.0510\end{array}$ & $\begin{array}{l}\text { I. } 145^{2} \\
0.0640\end{array}$ & $\begin{array}{l}I \cdot 1626 \\
0.0768\end{array}$ & $\begin{array}{l}I \cdot 1605 \\
0.0694\end{array}$ \\
\hline $\begin{array}{l}\text { Triceps }+ \text { subscapular }+ \\
\text { supra-iliac }\end{array}$ & $\begin{array}{l}c \\
m\end{array}$ & $\begin{array}{l}I \cdot 1555 \\
0.0607\end{array}$ & $\begin{array}{l}\text { I.1575 } \\
0.0617\end{array}$ & $\begin{array}{l}I \cdot I 393 \\
0.0544\end{array}$ & $\begin{array}{l}r \cdot 1604 \\
0.0716\end{array}$ & $\begin{array}{l}\text { I. } 1689 \\
0.0787\end{array}$ & $\begin{array}{l}1 \cdot 1704 \\
0.0731\end{array}$ \\
\hline All four skinfolds & $\begin{array}{l}c \\
m\end{array}$ & $\begin{array}{l}I .1620 \\
0.063^{\circ}\end{array}$ & $\begin{array}{l}\mathrm{I} \cdot \mathrm{I} 6_{3} \mathrm{I} \\
0.066_{32}\end{array}$ & $\begin{array}{l}\mathrm{r} \cdot \mathrm{r} 422 \\
0.0544\end{array}$ & $\begin{array}{l}I \cdot 1620 \\
0.0700\end{array}$ & $\begin{array}{l}\text { I.I71 } 5 \\
0.0779\end{array}$ & $\begin{array}{l}1 \cdot 1765 \\
0.0744\end{array}$ \\
\hline
\end{tabular}

Chen (1953) and Young and her colleagues (Young, Blondin, Tensuan \& Fryer, 1963) found that there was apparently little alteration in the ratio, subcutaneous fat: deep body fat in women up to the age of $45^{-50}$, but for older women the proportion in the subcutaneous tissues became relatively decreased. Other data on the relationship between skinfolds and body density in individuals of different ages have been reported by Brozek \& Keys (1951), Brozek \& Mori (1958), Chinn \& Allen (1960), Steinkamp, Cohen, Gaffey, McKey, Bron, Siri, Sargent \& Isaacs (1965), and Pařizková \& Eiselt ( 1966 ). However, since the method in these studies for the estimation of total body fat was by densitometry, one of the basic assumptions was that the FFM has a fairly constant density which does not alter with age within that age-range. Whether or not this is valid is discussed below. 
Table 5 (cont.)

(b) Females

\begin{tabular}{|c|c|c|c|c|c|c|c|}
\hline Skinfold & & $16-19$ & $20-29$ & $30-39$ & $40-49$ & $50+$ & $16-68$ \\
\hline Biceps & $\begin{array}{l}c \\
m\end{array}$ & $\begin{array}{l}1 \cdot 0889 \\
0.0553\end{array}$ & $\begin{array}{l}1.0903 \\
0.0601\end{array}$ & $\begin{array}{l}1.0794 \\
0.05 \text { I I }\end{array}$ & $\begin{array}{l}1 \cdot 0736 \\
0.0492\end{array}$ & $\begin{array}{l}1.0682 \\
0.0510\end{array}$ & $\begin{array}{l}1.0871 \\
0.0593\end{array}$ \\
\hline Triceps & $\begin{array}{l}c \\
m\end{array}$ & $\begin{array}{l}I \cdot 1159 \\
0.0648\end{array}$ & $\begin{array}{l}1.1319 \\
0.0776\end{array}$ & $\begin{array}{l}\text { I. I I } 76 \\
0.0686\end{array}$ & $\begin{array}{l}I \cdot I 121 \\
0.069 I\end{array}$ & $\begin{array}{l}x \cdot 1160 \\
0.0762\end{array}$ & $\begin{array}{l}I+1278 \\
0.0775\end{array}$ \\
\hline Subscapular & $\begin{array}{l}c \\
m\end{array}$ & $\begin{array}{l}I \cdot 108 I \\
0.062 I\end{array}$ & $\begin{array}{l}I \cdot 1184 \\
0.07 \text { I } 6\end{array}$ & $\begin{array}{l}x \cdot 0979 \\
0.0567\end{array}$ & $\begin{array}{l}1.0860 \\
0.0505\end{array}$ & $\begin{array}{l}\text { I.0899 } \\
0.0590\end{array}$ & $\begin{array}{l}\text { I. I 1 } 100 \\
0.0669\end{array}$ \\
\hline Supra-iliac & $\begin{array}{l}c \\
m\end{array}$ & $\begin{array}{l}\mathrm{I} \cdot 093 \mathrm{I} \\
0.0470\end{array}$ & $\begin{array}{l}1 \cdot 0923 \\
0.0509\end{array}$ & $\begin{array}{l}1.0860 \\
0.0497\end{array}$ & $\begin{array}{l}1.0691 \\
0.0407\end{array}$ & $\begin{array}{l}1 \cdot 0656 \\
0.0419\end{array}$ & $\begin{array}{l}I \cdot 0884 \\
0.05 I 4\end{array}$ \\
\hline Biceps + triceps & $\begin{array}{l}c \\
m\end{array}$ & $\begin{array}{l}I \cdot 1290 \\
0.0657\end{array}$ & $\begin{array}{l}I \cdot 1398 \\
0.0738\end{array}$ & $\begin{array}{l}I \cdot I 243 \\
0.0646\end{array}$ & $\begin{array}{l}I \cdot 1230 \\
0.0672\end{array}$ & $\begin{array}{l}I \cdot 1226 \\
0.0710\end{array}$ & $\begin{array}{l}I \cdot 1362 \\
0.0740\end{array}$ \\
\hline Biceps + subscapular & $\begin{array}{l}c \\
m\end{array}$ & $\begin{array}{l}I \cdot I 24 \text { I } \\
0.0643\end{array}$ & $\begin{array}{l}I \cdot 13 I 4 \\
0.0706\end{array}$ & $\begin{array}{l}I \cdot I I 20 \\
0.058 I\end{array}$ & $\begin{array}{l}I \cdot 103 I \\
0.0549\end{array}$ & $\begin{array}{l}I \cdot 1029 \\
0.0592\end{array}$ & $\begin{array}{l}I \cdot 1245 \\
0.0674\end{array}$ \\
\hline Biceps + supra-iliac & $\begin{array}{l}c \\
m\end{array}$ & $\begin{array}{l}\text { I.III3 } \\
0.0537\end{array}$ & $\begin{array}{l}\text { I'I I I } 2 \\
0.0568\end{array}$ & $\begin{array}{l}I .1020 \\
0.0528\end{array}$ & $\begin{array}{l}I \cdot 092 I \\
0.0494\end{array}$ & $\begin{array}{l}I \cdot 0857 \\
0.0490\end{array}$ & $\begin{array}{l}I \cdot 1090 \\
0.0577\end{array}$ \\
\hline Triceps + subscapular & $\begin{array}{l}c \\
m\end{array}$ & $\begin{array}{l}I \cdot 1468 \\
0.0740\end{array}$ & $\begin{array}{l}I \cdot 1582 \\
0.0813\end{array}$ & $\begin{array}{l}r \cdot 1356 \\
0.0680\end{array}$ & $\begin{array}{l}I \cdot 1230 \\
0.0635\end{array}$ & $\begin{array}{l}I \cdot 1347 \\
0.0742\end{array}$ & $\begin{array}{l}x \cdot x 507 \\
0.0785\end{array}$ \\
\hline Triceps + supra-iliac & $\begin{array}{l}c \\
m\end{array}$ & $\begin{array}{l}I \cdot I 3 \text { I I } \\
0.0624\end{array}$ & $\begin{array}{l}I \cdot 1377 \\
0.0684\end{array}$ & $\begin{array}{l}I \cdot I 28 \text { I } \\
0.0644\end{array}$ & $\begin{array}{l}I \cdot I 198 \\
0.0630\end{array}$ & $\begin{array}{l}I \cdot I \text { I } 58 \\
0.0635\end{array}$ & $\begin{array}{l}x \cdot \times 367 \\
0.0704\end{array}$ \\
\hline Subscapular + supra-iliac & $\begin{array}{l}c \\
m\end{array}$ & $\begin{array}{l}I \cdot 1278 \\
0.0616\end{array}$ & $\begin{array}{l}I \cdot 1280 \\
0.0640\end{array}$ & $\begin{array}{l}x \cdot x+32 \\
0.0564\end{array}$ & $\begin{array}{l}x \cdot 0997 \\
0.0509\end{array}$ & $\begin{array}{l}1.0963 \\
0.0523\end{array}$ & $\begin{array}{l}I \cdot 1234 \\
0.0632\end{array}$ \\
\hline Biceps + triceps + subscapular & $\begin{array}{c}c \\
m\end{array}$ & $\begin{array}{l}I \cdot 1509 \\
0.07 \times 5\end{array}$ & $\begin{array}{l}I \cdot 1605 \\
0 \cdot 0777\end{array}$ & $\begin{array}{l}I \cdot r_{385} \\
0.0654\end{array}$ & $\begin{array}{l}\mathbf{1} \cdot 1303 \\
0.0635\end{array}$ & $\begin{array}{l}\mathbf{I} \cdot 1372 \\
0 \cdot 07 \times 0\end{array}$ & $\begin{array}{l}I \cdot I 543 \\
0 \cdot 0756\end{array}$ \\
\hline Biceps + triceps + supra-iliac & $\begin{array}{l}c \\
m\end{array}$ & $\begin{array}{l}1 \cdot 138 z \\
0.0628\end{array}$ & $\begin{array}{l}I \cdot I 44 I \\
0.0680\end{array}$ & $\begin{array}{l}I \cdot 1319 \\
0.0624\end{array}$ & $\begin{array}{l}I \cdot 1267 \\
0.0626\end{array}$ & $\begin{array}{l}I \cdot 1227 \\
0.0633\end{array}$ & $\begin{array}{l}I \cdot I 432 \\
0.0696\end{array}$ \\
\hline $\begin{array}{l}\text { Biceps }+ \text { subscapular }+ \\
\text { supra-iliac }\end{array}$ & $\begin{array}{l}c \\
m\end{array}$ & $\begin{array}{l}I \cdot I 355 \\
0.0622\end{array}$ & $\begin{array}{l}I \cdot I 366 \\
0.0648\end{array}$ & $\begin{array}{l}I \cdot 1212 \\
0.0570\end{array}$ & $\begin{array}{l}I \cdot 1108 \\
0.0536\end{array}$ & $\begin{array}{l}I \cdot 1063 \\
0.0544\end{array}$ & $\begin{array}{l}I \cdot 1530 \\
0.0727\end{array}$ \\
\hline $\begin{array}{l}\text { Triceps + subscapular }+ \\
\text { supra-iliac }\end{array}$ & $\begin{array}{l}c \\
m\end{array}$ & $\begin{array}{l}x \cdot 1517 \\
0.0689\end{array}$ & $\begin{array}{l}1 \cdot 1566 \\
0 \cdot 0728\end{array}$ & $\begin{array}{l}I \cdot 1397 \\
0.0646\end{array}$ & $\begin{array}{l}I \cdot 1278 \\
0.0609\end{array}$ & $\begin{array}{l}I \cdot 1298 \\
0.0650\end{array}$ & $\begin{array}{l}I \cdot 1327 \\
0.0643\end{array}$ \\
\hline All four skinfolds & $\begin{array}{l}c \\
m\end{array}$ & $\begin{array}{l}I \cdot 1549 \\
0.0678\end{array}$ & $\begin{array}{l}I \cdot 1599 \\
0.0717\end{array}$ & $\begin{array}{l}x \cdot 1423 \\
0.0632\end{array}$ & $\begin{array}{l}I \cdot 1333 \\
0.0612\end{array}$ & $\begin{array}{l}\text { I. I339 } \\
0.0645\end{array}$ & $\begin{array}{l}\text { I. } 1567 \\
0.0717\end{array}$ \\
\hline
\end{tabular}

Independent of ageing, the nature of this distribution of subcutaneous and internal fat has been commented on by several authors but there is considerable variation, and indeed contradiction, in their respective findings. Vierordt ( 1906 ) reported that about half the total fat content of the body is subcutaneous and this value is sometimes quoted in general texbooks. Edwards (1950) found that in women the proportion of the total fat which was laid down subcutaneously rose with increasing obesity. Pochin (see Edwards, 1950) estimated, in forty-three women, that about $70 \%$ of adipose tissue was subcutaneous. Allen, Peng, Chen, Huang, Chang \& Fang (1956), from measurements on eighty-seven Formosan men and women, showed that the subcutaneous fat increased from a ratio of about $0.25-0.33$ of total body fat in lean individuals to about 0.5 in obese individuals. Alexander (1964) analysed fat distribution in twenty cadavers and found that the subcutaneous fat accounted for only $0 \cdot 2$ of the total fat in the men and $0 \cdot I$ in the women. 

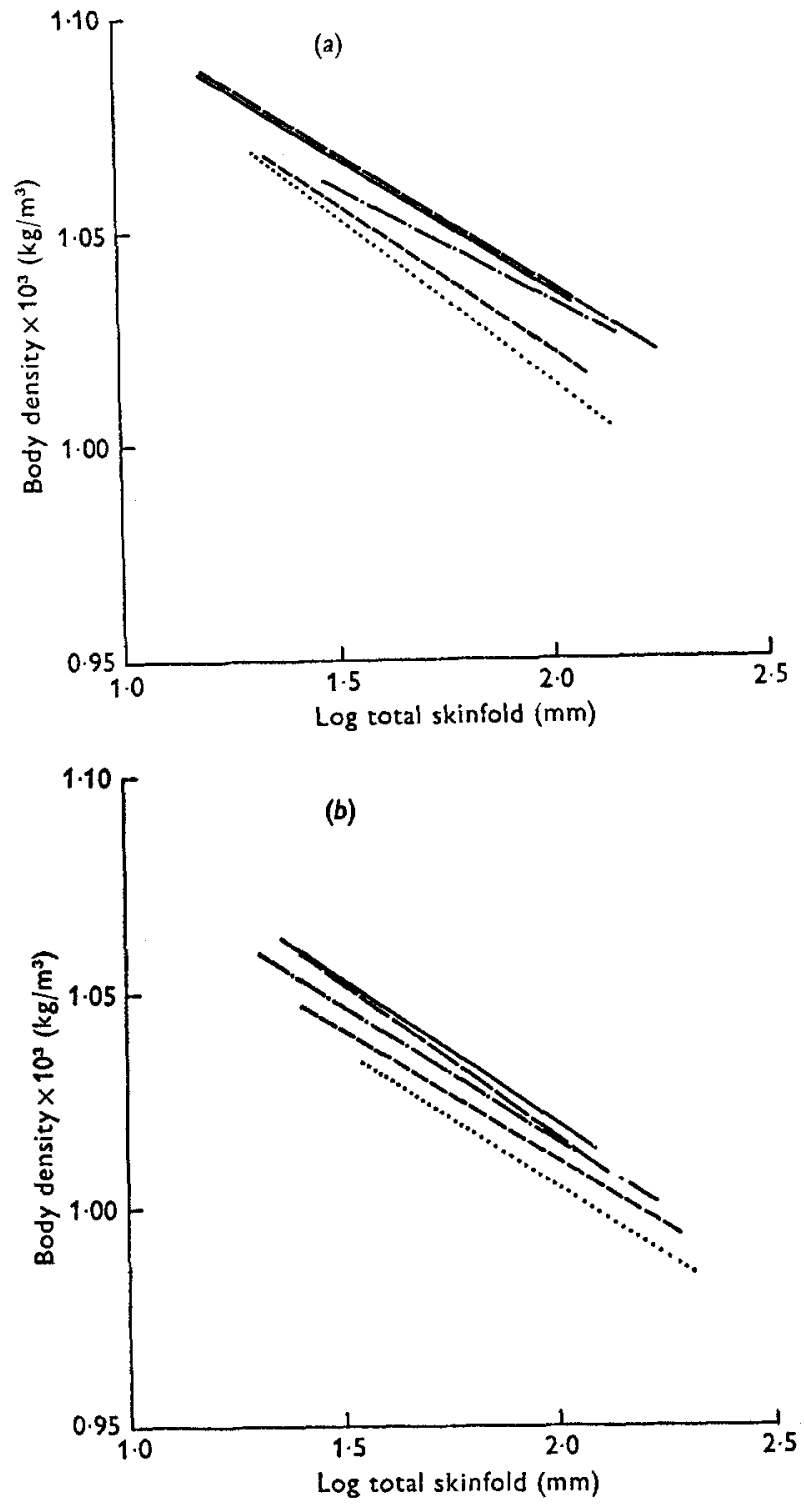

Fig. 3 (a) Regressions for log total skinfold thickness and whole body density for different age-groupings (males): -, I 7-r9 years; - -, 20-29 years; - - , 30-39 years; ---, 40-49 years; ....., 50+years. (b) Regressions for log total skinfold thickness and whole body density for different age-groupings (females): - , I6-19 years; $-\ldots, 20-29$ years; $-\cdot-, 30-39$ years;,$--- 40-49$ years; $. . . \ldots, 50+$ years.

One of the most interesting discussions on this topic appears in the paper by Forbes \& Amirhakimi (1970) on their measurements of ${ }^{40} \mathrm{~K}$ and skinfolds of 293 boys aged $8 \cdot 5^{-1} 8$ years and 179 girls aged $7 \cdot 5^{-1} 8$ years. These authors found, as we did in the present study, that males may have a higher proportion of their body fat situated subcutaneously than do females.

In two human subjects, in whom the distribution of the adipose tissue was measured, 

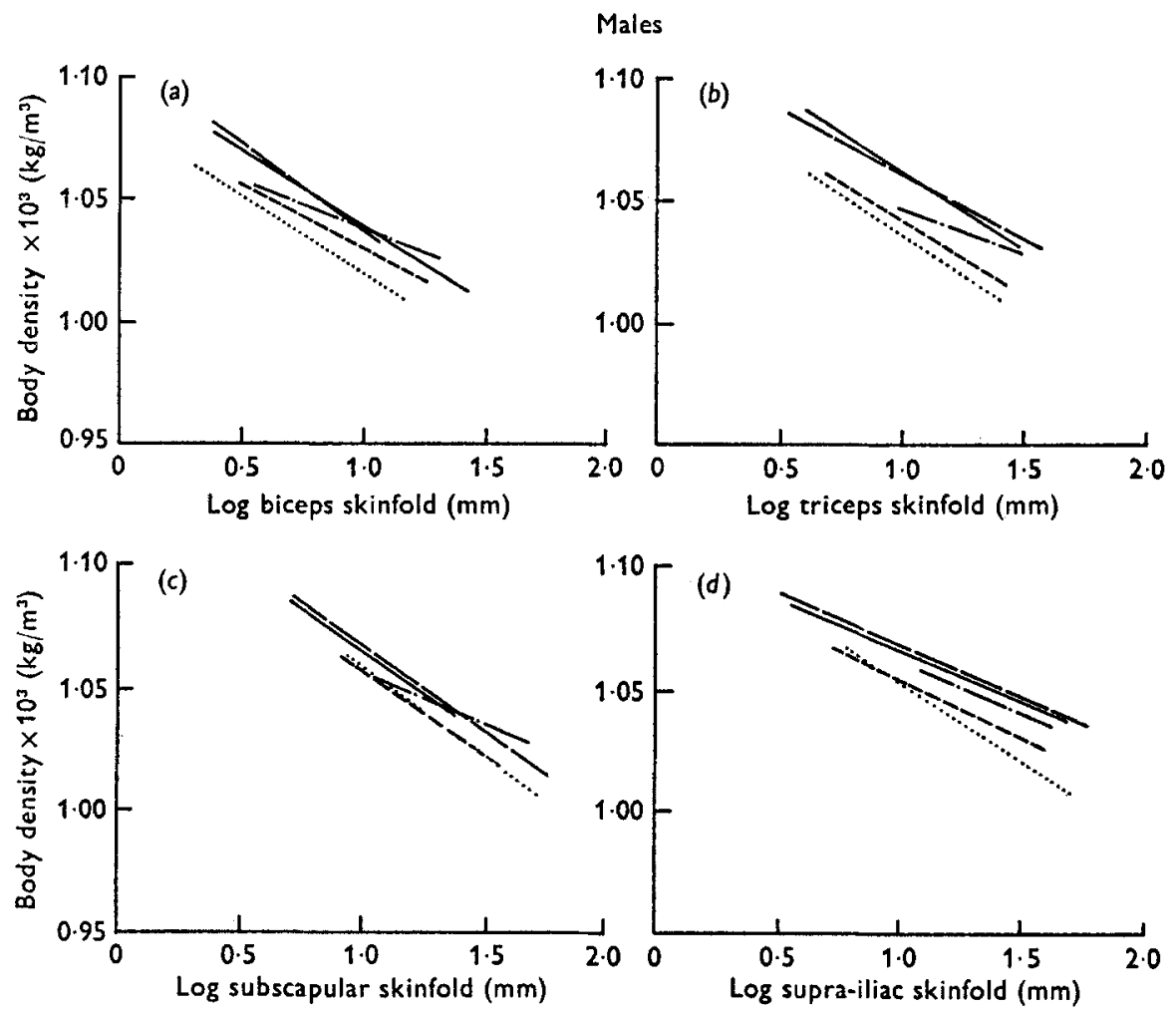

Fig. 4. Regressions for log of single skinfolds and whole body density for different agegroupings (males): (a) biceps; $(b)$ triceps; $(c)$ subscapular; $(d)$ supra-iliac. -, 17-19 years; ,$- 20-29$ years; $-\cdot-, 30-39$ years;,$--- 40-49$ years; $\ldots . . ., 50+$ years.

Forbes (1962) found in a neonate that $42 \%$ was in the subcutaneous tissues and Moore, Lister, Boyden, Ball, Sullivan \& Dagher (1968), in an elderly woman who had died of cancer, assessed the value at $32 \%$.

In studies on animals, Pitts (1956) from analyses of seventy-two guinea-pig carcasses, concluded that the proportion of total body fat situated subcutaneously remained constant for all degrees of fatness; the actual values were $16 \%$ in the males and $22 \%$ in the females.

In later work on thirty-two non-primate mammalian species, Pitts \& Bullard (1968) found the proportion of the total fat located subcutaneously to vary from 4 to $43 \%$.

The range of values from these authors is great and the uncertainty of the proportion of total body fat which is situated subcutaneously is not widely appreciated, even by workers in the subject. For example, in a recent publication on the composition of adipose tissue at subcutaneous sites, Brook (197I) states: 'However, because the majority of adipose tissue is subcutaneous ....' Further work clearly needs to be carried out on this aspect of body composition. 

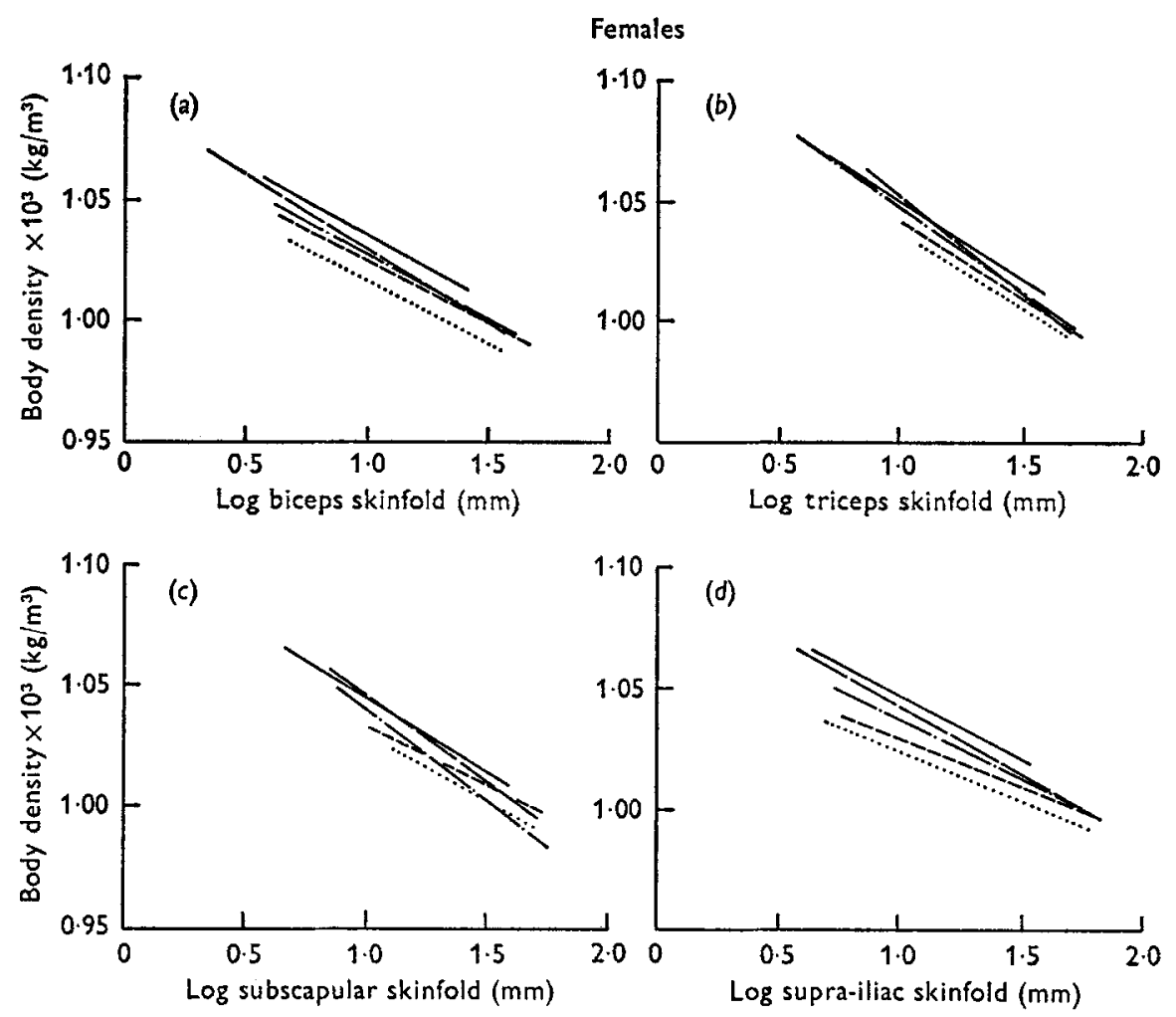

Fig. 5. Regressions for log of single skinfolds and whole body density for different agegroupings (females): $(a)$ biceps; $(b)$ triceps; $(c)$ subscapular; $(d)$ supra-iliac.,- I6-1 9 years;

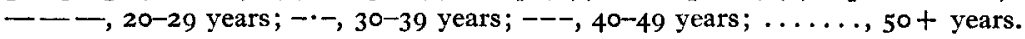

Table 6. F-statistics for testing equality of regression coefficients for five age-groups in the regression of skinfold thickness on body density. The degrees of freedom are 4 and 199 for males, and 4 and 262 for females

\begin{tabular}{lccccc} 
& Biceps & Triceps & Subscapular & Supra-iliac & Total \\
Males & I.89 & 1.33 & 2.88 & $\mathrm{r} \cdot 30$ & $\mathrm{r} .03$ \\
\multirow{2}{*}{ Females } & NS & NS & $*$ & NS & NS \\
& 0.75 & 0.46 & 1.93 & 0.56 & 0.59 \\
& NS & NS & NS & NS & NS
\end{tabular}

NS, not significant.

$$
* P<0.05 \text {. }
$$

(b) Variation in skinfold compressibility

A second possible reason for the shift in the relationship between body density and skinfold thickness with age is that skinfold compressibility may become greater in older people. The available evidence, however, suggests that the converse is true. Hammond (I955) reported skinfold compressibility of $42-43 \%$ in children, Garn (1956) and Garn \& Gormon (1956) skinfold compressibility of $30-35 \%$ in $21-$ to $22-$ year-old men, and Brozek \& Mori (1958) skinfold compressibility of $16 \%$ in $5^{6-\text { to }}$ 62 -year-old men. In all these investigations $\mathrm{X}$-radiography was used as a standard for 
Table 7. Common slope and intercept estimates from instances where regression coefficients are not significantly different

\begin{tabular}{|c|c|c|c|c|c|}
\hline & Biceps & Triceps & Subscapular & Supra-iliac & Total \\
\hline \multicolumn{6}{|c|}{ Males } \\
\hline Common slope & $0.0573 I$ & 0.05523 & - & 0.04564 & 0.06496 \\
\hline \multicolumn{6}{|l|}{ Intercept } \\
\hline 16-19 years & $x \cdot 0998$ & $I \cdot I 183$ & - & I $\cdot$ I I 3 I & $I \cdot I 653$ \\
\hline $20-29$ years & $x \cdot 0989$ & I. I I 55 & - & $I \cdot I I 45$ & $I \cdot 1659$ \\
\hline $30-39$ years & $x .0923$ & $I \cdot 1030$ & - & $I \cdot 1080$ & $x \cdot 1607$ \\
\hline $40-49$ years & $x \cdot 088 \mathrm{I}$ & I.0984 & - & 1.0995 & $I \cdot 1533$ \\
\hline $50-59$ years & $\mathbf{I} \cdot 0800$ & 1.0917 & - & [.0944 & $r \cdot 1490$ \\
\hline \multicolumn{6}{|c|}{ Females } \\
\hline Common slope & 0.05492 & 0.07284 & 0.06248 & 0.04765 & 0.067 II \\
\hline \multicolumn{6}{|l|}{ Intercept } \\
\hline 16-19 years & I. 0884 & $I \cdot I 253$ & $I \cdot 1085$ & I.0938 & $I \cdot I 537$ \\
\hline $20-29$ years & 1.0855 & I' 1259 & $I \cdot 1076$ & 1.0886 & $I \cdot 1518$ \\
\hline $30-39$ years & $\mathrm{r} \cdot 0832$ & $1 \cdot 1233$ & $\mathrm{I} \cdot \mathrm{T} 054$ & 1.0835 & I'I 495 \\
\hline $40-49$ years & I.0798 & $I \cdot I I 7 I$ & I. IOI 5 & 1.0775 & I'I 443 \\
\hline $50-59$ years & $x .0725$ & I'III 5 & $1 \cdot 0952$ & $1.073^{\circ}$ & $I \cdot 1389$ \\
\hline
\end{tabular}

Table 8. F-statistics for the analysis of covariance of skinfold thickness on body density for five age-groups. The degrees of freedom are 4 and 203 for males, and 4 and 266 for females

\begin{tabular}{|c|c|c|c|c|c|}
\hline & Biceps & Triceps & Subscapular & Supra-iliac & Total \\
\hline Males & $\begin{array}{r}2 \Gamma \cdot 90 \\
* * * *\end{array}$ & $\begin{array}{r}39 \cdot 70 \\
* * * *\end{array}$ & - & $\begin{array}{r}24 \cdot 88 \\
* * *\end{array}$ & $\begin{array}{r}26 \cdot 07 \\
* * * *\end{array}$ \\
\hline Females & $\begin{array}{r}10.85 \\
* * * *\end{array}$ & $\begin{array}{r}12.85 \\
* * * *\end{array}$ & $\begin{array}{l}9 \cdot 63 \\
* * *\end{array}$ & $\begin{array}{r}16 \cdot 85 \\
* * *\end{array}$ & $\begin{array}{r}12.93 \\
* * * *\end{array}$ \\
\hline
\end{tabular}

comparison of the skinfolds and the calipers exerted a pressure of $9.8 \times 10^{4} \mathrm{~N} / \mathrm{m}^{2}$. In the investigations of Hammond and of Garn compressibility was not influenced by the thickness of the skinfold (Brozek \& Mori did not assess this). Brozek \& Kinsey (I960) used calipers which exerted pressures of either $4^{\circ} 9,9^{\cdot 8}$ or $19^{.6} \times 10^{4} \mathrm{~N} / \mathrm{m}^{2}$ to study the influence of age on skinfold compressibility in $107 \mathrm{men}$, and they found a tendency for skinfold compressibility to decrease with age although this was of statistical significance at only two of the four sites measured. They suggested that this decrease in skinfold compressibility with age may be due to a reported decrease in the water content of the tissues present in the skinfold.

Although changes in skinfold compressibility do not apparently account for the altered relationships we have found between body density and skinfold thickness (and in fact have the opposite effect) they may be responsible for a proportion of the difference between the sexes; a possible sex difference in skinfold compressibility, however, has apparently not been reported. 


\section{(c) Density of the skeleton and ageing}

Apart from a change in the proportion of body fat in the subcutaneous tissues resulting from ageing, a second possible cause for the shift in position of the regression line with age is that the density of the FFM may alter. The most likely source of any alteration is in the skeleton. Sorenson, Mazess, Smith, Clark \& Cameron (I968) measured the mineral content of the radius over a transverse path one-third of the distance between the distal and proximal end. A photon absorptiometric technique was used. This was done on 327 boys and girls between the ages of 6 and 17 years, and on 390 adults between 18 and over 75 years of age; none of the subjects was known to suffer from any bone disease. Results were expressed as $g$ of mineral per unit length of bone. In the males the mineral content of the bone increased steadily from about $5 \circ \mathrm{g} / \mathrm{m}$ at age 6 years to about $13 \circ \mathrm{g} / \mathrm{m}$ at age 20 ; it then remained fairly constant until age 50-60 years but thereafter fell gradually to about $120 \mathrm{~g} / \mathrm{m}$ at age 75 . In females over the age of about $\mathrm{I} 2$ years the bone mineral content increased less rapidly than in the males, reaching a peak of about $100 \mathrm{~g} / \mathrm{m}$ at age $30-35$ years; a decline then followed to values of about $70 \mathrm{~g} / \mathrm{m}$ at age 80 years but, as with the men, the mineral content of the radius at age $40-50$ years was about the same as at 20 years.

Smith, Anderson, Shimmins, Speirs \& Barnett (I969) used an X-ray absorption technique to assess the mineral content of the third metacarpal bone of 312 males and $3^{1} 7$ females aged between about 2 and 88 years. A measure of the bone mineral was the 'standardized aluminium equivalent' (SAE), which was derived from the amount of mineral in the path of the X-ray beam divided by the external diameter of the metacarpal. In the males the mean SAE was about 32 in the late teens, rose to 34 at age 25 and remained at this level until age 55 ; thereafter the value declined slightly to 32 and remained there from age 65 up to about 80 years. In the females the mean SAE was about 33 at age 15 , remained about 35 till age 50 , then declined to about 28 at age 65 . The main difference between the sexes is the rapid decline in the mineral content of the bone which takes place in women soon after the menopause.

Smith et al. (1969) quoted several authors who have reported similar losses, with ageing, of mineral content from the humerus, femur and vertebrae. If, however, the demineralization of the metacarpal (Smith et al. 1969 ) and of the radius (Sorenson $e$ t al. 1968 ) is representative of changes which take place with age in all the bones of the body then this would mean that, from the age of 50 , women seem to lose about $\mathrm{r} \%$ of the mineral content per year whereas for men the loss from the body is only about one-third of this from age 50 to 75 .

Baker \& Angel (1965) measured the density (from mass and actual volume of bone substance) of the dry fat-free bone, the ash density, the protein density and the ash content of dry fat-free bone, in bone segments taken from forty-eight cadavers dissected in the anatomy departments of two American medical schools. All the cadavers were of individuals over 40 years of age and most were over 65 (mean age was 62 years for the Negro males and ranged from 70 to 74 years for the Negro females and the White groups). Segments of bone were taken for analysis from the 7 th thoracic vertebra, the 8 th rib, the tibia, the fibula, the calcaneus, the radius and the ulna of each 
cadaver. The density of different bone segments was found to vary considerably in the same cadaver and so the density of any one bone segment was a poor indication of the density of other bone segments or of total skeletal density in the same individual. The density of the segments was significantly higher in the Negro males than in the White males but there was no such racial difference in the females. In both these groups of elderly Negroes and Whites, the density of almost all bone segments was higher in the males than in the females and this was due to a lower mineral content in the bones of these elderly females. Some association between age and density was found in most bone segments, except in the group of Negro males, although this was not often statistically significant; the lack of statistical significance is perhaps less surprising than the authors suggest in view of the relatively small number of specimens and the somewhat advanced age of the individuals.

Baker \& Little (1965) made similar measurements to those described above on the cadavers of eighteen males from Lima, Peru, and seventeen males and thirteen females from the highlands of Peru; the ages ranged from about 20 to 80 years. The density of almost all those parts of the skeleton which were measured appeared to decrease with age in these groups.

Trotter \& Peterson (1955) analysed most of the individual bones of the complete skeletons of seven male cadavers and the limb bones only in another ten male cadavers, aged between $4 \mathrm{r}$ and 89 years. In the complete skeletons it was found that the ash contents of the separate bones was similar and was usually within $5 \%$ of the value for the skeleton as a whole. When two age-groups, $4 \mathrm{I}-60$ years and $6 \mathrm{I}-89$ years, were compared, a tendency for the ash content of bone to decrease with age was apparent, but only to the extent of about $1 \cdot 5 \%$. However, ash content was expressed as a percentage of the fat-free weight of bone, and changes in this reflect only an altcration in the balance between the organic and inorganic components of bone; changes in the absolute mineral content of bone would not be demonstrated by this method.

Trotter, Broman \& Peterson (1959) studied eighty skeletons - twenty in each of four groups (Negroes and Whites, males and females) - with an age-range of $45^{-80}$ years. The mean densities of the cervical and lumbar vertebrae, and of the humerus and femur, were $10 \%$ higher in the men than in the women and about the same amount higher in the Negroes than in the Whites. In both races there was a tendency for the mean density of all four bones to decrease with age. There were differences in the density of the four bones in the same skeleton.

In view of this evidence, culled from several different sources where there had been a variety of experimental techniques, it seems that there is a real decrease in the mineral content of the body from middle age onwards. Estimates of the rate of this decrease in total body mineral content vary from about 8 to $15 \%$ in men between the ages of 50 and 75 ; for the women the range is from about $18 \%$ up to about $30 \%$ from age 45 to 75 years. These values are based on estimates obtained for the apparent rates of demineralization of bone at certain selected sites and it may not be appropriate to extrapolate these findings to the skeleton as a whole; Mainland (1957), for example, has found that although the density of the middle phalange of the fifth finger appears to decrease with age, there appears to be no such alteration in the density of the 
metacarpal, lunate, capitate or radius bones. However, in the absence of more extensive information, it may not be unreasonable to use some of the above values to investigate the possible influence of changes in the body mineral content on the density of the fat-free mass.

The fat-free mass is composed of about $72 \%$ water, of density $1 \cdot 00 \times 10^{3} \mathrm{~kg} / \mathrm{m}^{3}$, $20 \%$ protein, of density $1.34 \times 10^{3} \mathrm{~kg} / \mathrm{m}^{3}$, and about $7 \%$ mineral, of density about $3.00 \times 10^{3} \mathrm{~kg} / \mathrm{m}^{3}$ (a little less than I \% will be carbohydrate) and the density of a fatfree mass of this composition is about $I \cdot I \mathrm{I} \times 10^{3} \mathrm{~kg} / \mathrm{m}^{3}$. A fall in the mineral content of the body of the order of $8 \%$ is equivalent to a fall in density of the fat-free mass of about $0.003 \times 10^{3} \mathrm{~kg} / \mathrm{m}^{3}$. A $15 \%$ change in mineral content corresponds to a fall in density of the fat-free mass of about $0.006 \times 10^{3} \mathrm{~kg} / \mathrm{m}^{3}$. This rate of demineralization would not account, in our results on the men, for the difference in the position of the regression lines relative to the vertical axis. For the women, the maximum decrease in mineral content which has been reported $(30 \%)$ would just about explain the different positions of the regression lines.

\section{(d) Changes in FFM with obesity}

The water content of the fat-free mass probably decreases with age but it is unlikely that changes in either this or in the protein content of the fat-free mass could be responsible for the observed changes in the position of the regression lines with age. A further possibility, however, is that the greater obesity in older people may be an important factor in that it alters the density of the FFM.

The calculated values for the fat-free mass of our male and female subjects are about 60 and $44 \mathrm{~kg}$ respectively, with little variation for the different age-groups. The fat content of the body, however, shows a marked increase with age: in the men from a mean value of about II $\mathrm{kg}$ fat in the I7- to 29 -year-old group, to over $22 \mathrm{~kg}$ in the group aged 50 years and older, and in the women from a mean value of about $15 \mathrm{~kg}$ fat in the 17 - to 29 -year-old group, to about $27 \mathrm{~kg}$ in the over 50 -year-olds. It is, however, the adipose tissue component of the body that tends to increase with age, not fat alone, and adipose tissue comprises about $64 \%$ fat, $22 \%$ 'cell residue' and I $4 \%$ extracellular water (Brozek et al. I963). The added 'cell residue' and extracellular water become a part of the fat-free mass. Since the density of water at $37^{\circ}$ is approximately unity and that of the 'cell residue' is about $1 \cdot 078 \times 10^{3} \mathrm{~kg} / \mathrm{m}^{3}$ (Brozek et al. $\mathrm{1}_{963}$ ) this addition to the fat-free mass has the relatively low density of about $\mathrm{I} \cdot 047 \times 10^{3} \mathrm{~kg} / \mathrm{m}^{3}$ and increase in the fat content of the body is thus accompanied by a fall in the density of the fat-free mass. The observed mean changes in adiposity with increasing age of our male and female subjects would bring about a mean reduction in the density of the fat-free mass of only about $0.003 \times 10^{3} \mathrm{~kg} / \mathrm{m}^{3}$ in the men and about $0.004 \times 10^{3} \mathrm{~kg} / \mathrm{m}^{3}$ in the women.

It would thus appear that the observed change with age in the relationship between skinfold thickness and body density is unlikely to be accounted for by changes in the composition of the fat-free mass. The conclusion is that it is due to a decrease in the proportion of the total body fat which is subcutaneous.

It therefore seems justifiable to assume, for the age-range of subjects in the present 
Table 9. The equivalent fat content, as a percentage of body-weight, for a range of values for the sum of four skinfolds (biceps, triceps, subscapular and supra-iliac) of males and females of different ages

\begin{tabular}{|c|c|c|c|c|c|c|c|c|}
\hline \multirow{2}{*}{$\begin{array}{l}\text { Skinfolds } \\
\text { (mm) }\end{array}$} & \multicolumn{4}{|c|}{ Males (age in years) } & \multicolumn{4}{|c|}{ Females (age in years) } \\
\hline & $17-29$ & $30-39$ & $40-49$ & $50+$ & $16-29$ & $30-39$ & $40-49$ & $50+$ \\
\hline I 5 & 4.8 & - & 一 & - & $10 \cdot 5$ & - & - & - \\
\hline 20 & $8 \cdot 1$ & $12 \cdot 2$ & $12 \cdot 2$ & I2. 6 & $14 \cdot 1$ & $17 \cdot 0$ & $19 \cdot 8$ & $2 I \cdot 4$ \\
\hline 25 & $10 \cdot 5$ & $14 \cdot 2$ & 15.0 & $15 \cdot 6$ & 16.8 & 19.4 & $22 \cdot 2$ & $24: 0^{\circ}$ \\
\hline 30 & $12 \cdot 9$ & $16 \cdot 2$ & 17.7 & I $8 \cdot 6$ & 19.5 & $2 I \cdot 8$ & $24 \cdot 5$ & $26 \cdot 6$ \\
\hline 35 & 147 & I $7 \cdot 7$ & 19.6 & 20.8 & $2 I \cdot 5$ & 23.7 & $26 \cdot 4$ & $28 \cdot 5$ \\
\hline 40 & 16.4 & $19 \cdot 2$ & $2 I \cdot 4$ & $22 \cdot 9$ & 23.4 & $25 \cdot 5$ & $28 \cdot 2$ & $30 \cdot 3$ \\
\hline 45 & $17 \cdot 7$ & 20.4 & $23 \cdot 0$ & 247 & $25 \cdot 0$ & $26 \cdot 9$ & $29 \cdot 6$ & $3 \mathbf{r} \cdot 9$ \\
\hline 50 & 19.0 & $2 r \cdot 5$ & $24 \cdot 6$ & $26 \cdot 5$ & $26 \cdot 5$ & $28 \cdot 2$ & $3 I \cdot 0$ & $33 \cdot 4$ \\
\hline 55 & $20 \cdot 1$ & $22 \cdot 5$ & 25.9 & $27^{\circ} 9$ & $27 \cdot 8$ & $29 \cdot 4$ & $32 \cdot 1$ & $34 \cdot 6$ \\
\hline 60 & $2 I: 2$ & $23 \cdot 5$ & $27 \cdot 1$ & $29 \cdot 2$ & $29 \cdot 1$ & 30.6 & $33^{2} 2$ & $35 \cdot 7$ \\
\hline 65 & $22 \cdot 2$ & $24 \cdot 3$ & $28 \cdot 2$ & 30.4 & 30.2 & $3 x \cdot 6$ & 34.1 & $36 \cdot 7$ \\
\hline 70 & $23 \cdot 1$ & $25 \cdot 1$ & $29 \cdot 3$ & $3 I \cdot 6$ & $3 I \cdot 2$ & $3^{2 \cdot 5}$ & 35.0 & $37 \cdot 7$ \\
\hline 75 & 24.0 & $25 \cdot 9$ & 30.3 & 32.7 & $32 \cdot 2$ & 33.4 & $35^{\circ} 9$ & $38 \cdot 7$ \\
\hline 80 & 24.8 & $26 \cdot 6$ & $3 I \cdot 2$ & $33 \cdot 8$ & $33 \cdot I$ & $34 \cdot 3$ & 36.7 & $39 \cdot 6$ \\
\hline 85 & $25 \cdot 5$ & $27 \cdot 2$ & $32 \cdot I$ & $34 \cdot 8$ & $34 \circ 0$ & $35^{-1}$ & $37 \cdot 5$ & $40 \cdot 4$ \\
\hline 90 & $26 \cdot 2$ & $27 \cdot 8$ & 33.0 & $35 \cdot 8$ & 34.8 & $35 \cdot 8$ & $38 \cdot 3$ & $41 \cdot 2$ \\
\hline 95 & 26.9 & $28 \cdot 4$ & 33.7 & $3^{6 \cdot 6}$ & $35 \cdot 6$ & $3^{6 \cdot 5}$ & 39.0 & $4 I^{\circ} 9$ \\
\hline 100 & $27 \cdot 6$ & 29.0 & 344 & $37^{\circ} 4$ & 36.4 & $37 \cdot 2$ & 39.7 & $42 \cdot 6$ \\
\hline 105 & $28 \cdot 2$ & $29 \cdot 6$ & $35 \cdot I$ & $38 \cdot 2$ & $37 \cdot 1$ & $37 \cdot 9$ & 40.4 & 43.3 \\
\hline IIO & 28.8 & 30.1 & 35.8 & 39.0 & $37 \cdot 8$ & $38 \cdot 6$ & $41 \cdot 0$ & 43.9 \\
\hline I I 5 & $29 \cdot 4$ & 30.6 & $36 \cdot 4$ & 39.7 & $38 \cdot 4$ & $39 \cdot 1$ & $41 \cdot 5$ & 44.5 \\
\hline 120 & 30.0 & $3 I \cdot I$ & $37^{\circ} \circ$ & $40 \cdot 4$ & 39.0 & 39.6 & $42 \cdot 0$ & $45 \cdot I$ \\
\hline 125 & 30.5 & $3 I \cdot 5$ & $37 \cdot 6$ & $4 I \cdot I$ & $39 \cdot 6$ & $40 \cdot 1$ & 42.5 & 45.7 \\
\hline 130 & $31 \cdot 0$ & $3 I \cdot 9$ & $38 \cdot 2$ & $41 \cdot 8$ & 40.2 & $40 \cdot 6$ & 430 & $46 \cdot 2$ \\
\hline 135 & $3 I \cdot 5$ & $32 \cdot 3$ & 387 & $42 \cdot 4$ & 40.8 & $4 \mathrm{I} \cdot \mathrm{I}$ & 43.5 & $46 \cdot 7$ \\
\hline 140 & $32 \cdot 0$ & $32 \cdot 7$ & $39: 2$ & 43.0 & $4 I \cdot 3$ & $4 x \cdot 6$ & $44^{\circ}$ & $47 \cdot 2$ \\
\hline I 45 & $32 \cdot 5$ & $33 \cdot I$ & 39.7 & $43 \cdot 6$ & $4 I \cdot 8$ & $42 \cdot I$ & 44.5 & $47 \cdot 7$ \\
\hline 150 & $32 \cdot 9$ & 33.5 & 40.2 & 44.1 & $42 \cdot 3$ & $42 \cdot 6$ & $45^{\circ}$ & $48 \cdot 2$ \\
\hline I 55 & $33 \cdot 3$ & 33.9 & 40.7 & $44 \cdot 6$ & $42 \cdot 8$ & $43^{\circ} \mathrm{I}$ & 45.4 & 48.7 \\
\hline 160 & 33.7 & $34 \cdot 3$ & $4 I \cdot 2$ & $45^{\prime} I$ & $43 \cdot 3$ & 43.6 & $45 \cdot 8$ & $49 \cdot 2$ \\
\hline 165 & $34^{\circ} \mathrm{I}$ & $34 \cdot 6$ & $4 I \cdot 6$ & $45 \cdot 6$ & $43 \cdot 7$ & $44^{\circ} 0$ & $46 \cdot 2$ & $49 \cdot 6$ \\
\hline 170 & $34: 5$ & $34 \cdot 8$ & $42 \cdot 0$ & $46 \cdot 1$ & $44 \cdot I$ & 44.4 & $46 \cdot 6$ & 50.0 \\
\hline 175 & 34.9 & - & - & - & - & 44.8 & $47^{\circ} \mathrm{O}$ & $50 \cdot 4$ \\
\hline 180 & $35^{\circ} 3$ & - & - & - & - & $45 \cdot 2$ & $47 \cdot 4$ & 50.8 \\
\hline 185 & $35 \cdot 6$ & - & - & - & - & $45 \cdot 6$ & $47 \cdot 8$ & $5 \times \cdot 2$ \\
\hline 190 & 35.9 & - & - & - & - & 45.9 & $48 \cdot 2$ & $5 x \cdot 6$ \\
\hline 195 & - & - & - & - & - & 46.2 & $48 \cdot 5$ & $52 \cdot 0$ \\
\hline 200 & - & - & - & - & - & $46 \cdot 5$ & $48 \cdot 8$ & $52 \cdot 4$ \\
\hline 205 & - & - & - & - & - & - & $49 \cdot I$ & 52.7 \\
\hline 210 & - & - & - & - & - & - & $49 \cdot 4$ & 53.0 \\
\hline
\end{tabular}

In two-thirds of the instances the error was within $\pm 3.5 \%$ of the body-weight as fat for the women and $\pm 5 \%$ for the men.

study, that the density of the FFM is a reasonably constant measurement and that equations can be derived for various age groupings to calculate density and body fat from skinfold thickness. In Table 5, equations were given from which density and body fat can be calculated from single skinfolds or from multiples of two or more skinfold thicknesses. Table 9 gives values of the fat content of the body, as a ratio of body-weight, corresponding to various values of the sum of the four skinfold thicknesses in both men and women divided into four age-groupings. The calculations 
have been made from the logarithmic transformation of the sum of the four skinfolds using the regression equations given in Table 5. There are some peculiarities about Table 9 which it is as well to point out. As a table for practical use in the great majority of people within these age-ranges, it should prove to be quite satisfactory and of reasonable reliability. Nevertheless, at the 'lean' end of the scale it is clear that more information will be needed before the table becomes really adequate. There are too large variations in body fat for too small variations in skinfolds, and a very low value for the total of four skinfolds $(20 \mathrm{~mm})$ is still equivalent to apparently having moderate quantities of fat. The reasons for this unsatisfactory state are basically a lack of fundamental information on FFM in women, although perhaps more complex mathematical treatment of information on large numbers of 'lean' women of all ages may improve the relationship. We are at present collecting more information.

Workers who have measured fewer than four skinfolds may construct a similar table. However, although the standard error is very little different when two, and perhaps even single skinfolds have been measured instead of four, there are occasional individuals where, because of unusual fat distribution, the likelihood of large error may be reduced by using multiple skinfolds.

The procedure described above for assessing total body fat with relative ease and reasonable accuracy on men and women of widely differing age should make it of common use in many fields of medicine, physiology, nutrition and anthropology.

We are very grateful to Dr R. A. Elton, Department of Virology, University of Glasgow, for help and advice about statistical aspects of the analysis and also to $\mathrm{Dr}$ Knill-Jones and Miss Mary Nicholson of the Department of Medicine in Relation to Mathematics and Computing, University of Glasgow. Mrs Margaret Band and $\mathrm{Mr}$ Robert Campbell gave much technical assistance.

Part of this work was supported by grants from the Medical Research Council and from the US Public Health Service (AM 5104).

\section{REFERENCES}

Alexander, M. L. (1964). Clin. Sci. 26, 193.

Allen, T. H., Peng, M. T., Chen, K. P., Huang, T. F., Chang, C. \& Fang, H. S. (1956). Metabolism 5, 346.

Baker, P. T. \& Angel, J. L. (1965). Hum. Biol. 37, ro4.

Baker, P. T. \& Little, M. A. (1965). Hum. Biol. 37, 122.

Brook, C. G. D. (197I). Br. F. Nutr. 25, 377.

Brozek, J. \& Keys, A. (1951). Br. F. Nutr. 5, x94.

Brozek, J. \& Kinsey, W. (1960). F. Geront. 15, 45.

Brozek, J. \& Mori, H. (1958). Hum. Biol. 30, 322.

Brozek, J., Grande, F., Anderson, J. T. \& Keys, A. (1963). Ann. N.Y. Acad. Sci. 110, I13.

Chen, K. P. (1953). F. Formosan med. Ass. 52, 271.

Chinn, K. S. K. \& Allen, T. H. (1960). Rep. U.S. Army med. Res. Nutr. Lab. no. 248.

Durnin, J. V. G. A. \& Rahaman, M. M. (1967). Br. F. Nutr. 21, 68I.

Edwards, D. A. W. (r950). Clin. Sci. 9, 259.

Edwards, D. A. W., Hammond, W. H., Healy, M. J. R., Tanner, J. M. \& Whitehouse, R. H. (I955). Br. F. Nutr. 9, 133 .

Forbes, G. B. (1962). Pediatrics, Springfield 29, 477.

Forbes, G. B. \& Amirhakimi, G. H. (1970). Hum. Biol. 42, 40r. 
Garn, S. M. (1956). Science, N.Y. 124, 178 .

Garn, S. M. \& Gormon, E. L. (1956). Hum. Biol. 28, 407.

Gwinup, G., Chelvam, R. \& Steinberg, T. (1971). Ann. intern. Med. 74, 408.

Hammond, W. H. (1955). Br.F. prev. soc. Med. 9, $20 \mathrm{r}$.

Mainland, D. (1957). F. Geront. 12, 284.

Moore, F. A., Lister, J., Boyden, C. M., Ball, M. R., Sullivan, N. \& Dagher, F. J. (I968). Hum. Biol. 40, 135 .

Pařízková, J. \& Eiselt, E. (1966). Hum. Biol. 38, 35 r.

Pitts, G. C. (1956). Am. F. Physiol. 185, 4r.

Pitts, G. C. \& Bullard, T. R. (I968). Publs natn. Acad. Sci., Wash. no. I 598, p. 45.

Rahn, H., Fenn, W. O. \& Otis, A. B. (1949). J. appl. Physiol. 1, 725.

Siri, W. E. (1956). Univ. Calif. Radiat. Lab. Publ. no. 3349.

Skerlj, B., Brozek, J. \& Hunt, E. E. (1953). Am. Y. phys. Anthrop. xг, 277.

Smith, D. A., Anderson, J. B., Shimmins, J., Speirs, C. F. \& Barnett, E. (1969). Clin. Radiol. $20,23$.

Sorenson, J. A., Mazess, R. B., Smith, E. L., Clark, J. A. \& Cameron, J. R. (1968). Bone Mineral and Body Composition: Progress Report. Wisconsin: University of Wisconsin.

Steinkamp, R. C., Cohen, N. L., Gaffey, W. R., McKey, T., Bron, G., Siri, W. E., Sargent, T. W. \& Isaacs, E. (1965). F. chron. Dis. 18, 1291.

Tanner, J. M. (1962). Growth at Adolescence 2nd ed. Oxford: Blackwell Scientific Publications.

Tanner, J. M. \& Whitehouse, R. H. (1962). Br. med. F. i, 446.

Trotter, M., Broman, G. E. \& Peterson, R. R. (1959). Am. $\mathscr{J}$. phys. Anthrop. 17, I9.

Trotter, M. \& Peterson, R. R. (1955). Anat. Rec. r23, 34I.

Vierordt, H. (I906). In Anatomische, Physiologische und Physikalische, Daten und Tabellen zum Gebrauch für Mediziner. Jena: Fischer.

Weiner, J. S. \& Lourie, J. A. (I969). In Human Biology: A Guide to Field Methods. I.B.P. Handbook no. 9. Oxford: Blackwell Scientific Publications.

Womersley, J. \& Durnin, J. V. G. A. (1973). Hum. Biol. 45, 28 I.

Young, C. M., Blondin, J., Tensuan, R. \& Fryer, J. H. (1963). F. Am. diet. Ass. 43, 344. 